\title{
PERFORMANCE AND FORECAST OF INDONESIAN RUBBER EXPORTS TO THE CENTRAL EUROPEAN COUNTRIES
}

\author{
Agus Dwi Nugroho, 2,* , Imade Yoga Prasada ${ }^{3}$, Zoltan Lakner ${ }^{1}$ \\ ${ }^{1}$ Doctoral School of Economic and Regional Sciences, Hungarian University of Agriculture \\ and Life Sciences \\ ${ }^{2}$ Faculty of Agriculture Universitas Gadjah Mada Indonesia \\ ${ }^{3}$ Study Program of Agribusiness, Faculty of Science and Technology, Universitas Putra \\ Bangsa, Kebumen 54361, Indonesia \\ agus.dwi.n@mail.ugm.ac.id
}

\begin{abstract}
The price and consumption of rubber experienced a decline due to the global economic crisis, the US-China trade war, and coronavirus. This situation is unprofitable for Indonesia, and it must develop new target markets. Central Europe is one of the potential markets for Indonesian rubber. This study aims to ascertain the performance of the Indonesian rubber exports to Central European countries and forecast its future. The research used Indonesian rubber export data to Hungary, Poland, and Romania from January 1999 to March 2021. Descriptive statistics and autoregressive integrated moving averages were used to analyze the data. In the last three decades, Indonesian rubber exports to Central Europe have risen. The short-term forecasting indicates that Indonesian rubber exports to Poland will increase; on the other hand, exports to Romania will experience a decline. Meanwhile, exports to Hungary were relatively stable. This result was obtained using ARIMA estimation with different models for each country, respectively $\operatorname{ARIMA}(1,0,5)$ in Poland, $\operatorname{ARIMA}(2,0,1)$ in Romania, and $\operatorname{ARIMA}(2,0,1)$ in Hungary.
\end{abstract}

Keywords: Hungary, Poland, Romania, ARIMA, increase, stagnate

Received 31 December 2021 Accepted 1 February 2022

\section{INTRODUCTION}

Southeast Asian countries are the world's leading producers and exporters of natural rubber. Compared to other countries globally, Thailand and Indonesia have the most competitive rubber crops [1]. Both countries were able to export $82 \%$ and $74 \%$ of their natural rubber production in 2018. But, in 2019, the production of Thailand and Indonesia decreased, causing world natural rubber production also decreased by $1.3 \%$ from the previous year [2].

Currently, the world rubber trade competition is getting tighter with the emergence of Malaysia and Vietnam as suppliers to other countries. Malaysian natural rubber exports have risen in volume over the last two decades. In the same period, Malaysian processed rubber exports rose by up to $400 \%$ [3]. Meanwhile, in the last two decades, Vietnam increased its rubber production and exports due to its strategy to build new rubber plantations on unproductive agricultural areas and degraded natural forest lands [4].

Nowadays, the four countries have agreed to establish an oligopoly and dominate $75 \%$ of the world rubber trade $[5,6]$. However, they were unable to control the price of rubber around the world completely. It tends to decline in the last five years [7]. On the other hand, world 
rubber consumption in 2019 was also estimated to decline by $0.7 \%$ due to the trade war between the US and China [2]. China's rubber imports from Southeast Asia declined as a result of this. Even though, China is one of the world's largest rubber consumers [8]. The Covid-19 also exacerbates this condition, so the world rubber consumption is expected to fall by $8.9 \%(12.544$ million tons in 2020) relative to the previous year

Indonesia is the most affected country by China's and the world's rubber trade uncertainty [8]. According to Antoni-Tokuda [9], this will harm the national economy of small farmers. They are the primary managers of the rubber industry in Indonesia. They have almost $85 \%$ of the rubber land, while private and government plantations manage the remainder. Meanwhile, the rubber price shocks in Indonesia will also impact other producer countries [10]. This situation is certainly unfavorable for Thailand, Malaysia, and Vietnam as rubber producers.

As a result, Indonesia needs to implement a new strategy, diversify the market, or find new target markets. Indonesia must take advantage of its business environment, especially its ability to produce rubber and expand its market share [11]. One of the potential rubber sales markets is Central European countries. Until now, countries in this region have relied on rubber imports. Their need increases due to the development of the industry [12-14].

In this way, a study of the performance and forecast of Indonesian rubber exports to Central European countries is essential. This study will improve Indonesian rubber exports, strengthen its competitiveness, and progress in the international trade competition. Meanwhile, this study is vital for Central European countries to ensure the supply of raw materials for their industries, or it is called supply chain management. The Covid-19 pandemic has thrown Central Europe's economy into disruption. As usual, an economic disruption will require a long recovery time and cause households or credit institutions to behave more carefully in spending money than before the crisis [15]. Nowadays, the rubber processing industry will be one of Central Europe's top picks for economic recovery after this pandemic [16]. This study also shows that a country does not only rely on comparative and competitive advantage theory but also on accuracy in choosing its target market. Moreover, studies on Indonesian rubber exports to Central Europe have never been conducted by other researchers.

\section{LITERATURE REVIEW}

\section{International Trade}

Many countries around the world desire globalization. There is a lot of ease in the flow of goods and services across borders, the movement of peoples and firms, the dissemination of cultures and ideas between countries, and the tight integration of financial markets across the world [17]. One of the exciting things is the trade of goods and services because many international institutions and agreements were initiated to create free trade. Many theories discuss trade, but the most popular in today's world is comparative advantage.

According to David Ricardo's law of comparative advantages that a country should specialize in the production and export of the commodity in which its absolute disadvantage is smaller (has a comparative advantage) and import of the commodity in which its absolute disadvantage is greater (has a comparative disadvantage) [18]. In order to compete in the trade competition, a country must achieve the highest comparative advantages of its products and services. It will be determining the pre-trade relative prices in each country, efficiency production method, terms of trade, and the gains to be had for its trading partners $[19,20]$.

Ricardo said that labor is the essential aspect of the comparative advantage, although some economic participants (capitalists, laborers, and landlords) and political economy are also involved in trade [21]. In fact, the country's comparative disadvantage can turn into a comparative advantage if they can manage labor costs lower than other countries [18]. The 
comparative advantage will affect the cost and price of a product or service. The producer with lower production and distribution costs will achieve a robust comparative advantage [19].

In particular, labor is not the only factor of production. There is also capital or another factor of production that allows substitution between these factors. Furthermore, labor ability and productivity also vary greatly, so it cannot be considered homogeneous, such as the assumption of comparative advantage [18]. The various controversies over low wages caused foreign trade unfairly, hurt other countries, and trade worse off [19]. Since this was such a severe shortcoming of the Ricardian model, it appears the Heckscher-Ohlin (H-O) model theoretically improves on and extends it.

The H-O model explains that comparative advantage is influenced by the interaction between countries' resources (the relative abundance of factors of production) and their production technologies (which influences the relative intensity with the different factors of production are used in the production of different goods). This model is also called the factorproduction theory because it emphasizes the interplay between the proportions in different production factors in different countries and how they are used in producing different products [19]. The HO model also identifies who benefits and who losses from opening trades. The intensively used factors in export products will have real gains if the relative price increases with trade openness but causes actual losses for other factors [17].

\section{Indonesia in The World Rubber Trades}

After Thailand, Indonesia is the world's second-largest rubber producer and exporter. According to the Ministry of Agriculture, rubber plantations are concentrated in Sumatra, specifically in South Sumatra, North Sumatra, Riau, and Jambi [9]. Around 80\% of Indonesian rubber production goes to the export market. Indonesian rubber is mainly exported to the United States, Japan, and China.

Other exporter countries are Thailand, Malaysia, and Vietnam. Although competing for the same market, it turns out Malaysia and Thailand also import rubber from Indonesia. This shows that Indonesian rubber has the same quantity and quality compared to both countries. In addition, this condition is an indicator of integrated rubber trade between Southeast Asian countries [22]. However, Singapore has the highest rubber trade connectivity with Indonesia, mainly centers in the Sumatra economic corridor, due to lower import costs than other ASEAN countries. Indonesian rubber trade integration with other ASEAN countries will be more robust if there is an increase in economic growth, farmers' welfare, and per capita income [23].

Several essential factors influence Indonesian rubber exports. For example, exchange rate volatility harms Indonesian rubber exports to India, Japan, South Korea, and the United States. Rubber exports to India will decrease due to high exchange rate volatility, both in the short and long term. Traders may be risk-averse due to high uncertainty. Exchange rate volatility will cause Indonesian rubber exports to South Korea to turn from positive to negative in the short term. A $1 \%$ rise in volatility is expected to result in a $0.5 \%$ reduction in exports in the long term. This change relates to the traders' ability to adjust the export volumes in the long run [24].

The price change will have a significant effect on Indonesian natural rubber exports. If the price of natural rubber drops by 1 US $\$$, the total exports could decrease by up to 30 tons. Meanwhile, one of Indonesia's ways to increase rubber exports is increasing production [25]. However, Indonesia can still return to equilibrium in the long run if there is a change in world rubber prices. Indonesia also has higher efficiency in adjusting its rubber prices than Malaysia and Vietnam [26]. 


\section{RESEARCH METHODS \\ Data}

The data used in this study was Indonesian monthly rubber exports to Central European countries from January 1999 to March 2021. The source of the data was obtained from Eurostat. The type of rubber used in this study was natural rubber, balata, gutta-percha, guayule, chicle and similar natural gums, in primary forms or plates, sheets or strips or HS 4001. The samples in this study are Hungary, Poland, and Romania because they are the leading importers of rubber from Indonesia [27]. We use STATA software to analyze the data

\section{Data Analysis}

In this study, we want to ascertain Indonesian rubber exports' performance and forecast the future to Central European countries. We use descriptive analysis to discuss about Indonesian rubber exports' performance. Meanwhile, an alternate analysis of AR (Autoregressive) or MA (Moving Average) or ARMA (Autoregressive Moving Average) or ARIMA (Autoregressive Integrated Moving Average) is utilized to forecast future Indonesian rubber exports. The use $\sigma$ of these analytical alternatives depends on the stationarity test. In this study, we used the Augmented Dicky-Fuller test to determine the data stationarity. The hypotheses used in the Augmented Dicky-Fuller test are:

$\mathrm{H}_{0}: \mathrm{Z}_{\text {stat }}>\mathrm{Z}_{\text {calc }}$, there is unit roots or variable is not stationary

$\mathrm{H}_{1}: \mathrm{Z}_{\text {stat }}<\mathrm{Z}_{\text {calc }}$, there is not unit roots or variable is stationary

Analysis of time series data is usually faced with non-stationary data problems. The data must be made stationary by using differencing. This can eliminate (or reduce) trends and seasonality by removing changes in the level of a time series [28]. We can use the analysis model in a variety of ways if a time series is stationary.

In this study, we intend to create forecasts for Indonesian rubber exports, which are indicated by $\mathrm{Y}$ at time $\mathrm{t}\left(\mathrm{Y}_{\mathrm{t}}\right)$. If we model $\mathrm{Y}_{\mathrm{t}}$ as:

$$
Y_{t}=\alpha_{1}\left(Y_{t-1}\right)+\mu_{t}
$$

notes:

$\delta=$ the mean of $\mathrm{Y}$

$\mu_{\mathrm{t}}=$ uncorrelated random error term with zero mean and constant variance $\sigma^{2}$ (white noise)

Model (1) in econometrics is known as a first-order autoregressive. or AR(1). In this model, the value of $\mathrm{Y}$ at time $\mathrm{t}$ is determined by its value in the previous period and a random term; the $\mathrm{Y}$ values are expressed as deviations from their mean value. But if we consider this model

$$
\mathrm{Y}_{\mathrm{t}}=\alpha_{1}\left(\mathrm{Y}_{\mathrm{t}-1}\right)+\alpha_{2}\left(\mathrm{Y}_{\mathrm{t}-2}\right)+\mu_{\mathrm{t}}
$$

then we say that $Y_{t}$ follows a second-order autoregressive, or $\operatorname{AR}(2)$, process. That is, the value of $Y$ at time $t$ is determined by its value in the previous two time periods, the $Y$ values are represented around their mean value $\delta$.

When (1) and (2) are combined, we can have

$$
\begin{gathered}
\mathrm{Y}_{\mathrm{t}}=\alpha_{1}\left(\mathrm{Y}_{\mathrm{t}-1}\right)+\alpha_{2}\left(\mathrm{Y}_{\mathrm{t}-2}\right)+\ldots . .+\alpha_{p}\left(\mathrm{Y}_{\mathrm{t}-\mathrm{p}}\right)+\mu_{\mathrm{t}} \\
\mathrm{Y}_{\mathrm{t}}=\sum_{i=1}^{p} \alpha_{i}\left(\mathrm{Y}_{\mathrm{t}-\mathrm{i}}\right)+\mu_{\mathrm{t}}
\end{gathered}
$$


in which case $\mathrm{Yt}$ is a pth-order autoregressive, or $\mathrm{AR}(\mathrm{p})$, process.

The AR process that we just discussed isn't the only one that may have resulted in Y. Assume we model $\mathrm{Y}$ in the following way:

$$
\mathrm{Y}_{\mathrm{t}}=\mu_{\mathrm{t}}+\beta_{0} \mu_{\mathrm{t}}+\beta_{1} \mu_{\mathrm{t}-1}
$$

In this model, the value of $\mathrm{Y}$ at time $\mathrm{t}$ is equal to a constant plus a moving average of the current and past error terms. Thus, in the present case, we say that $\mathrm{Y}$ follows a first-order moving average, or an MA(1), process. But if Y follows the expression

$$
\mathrm{Y}_{\mathrm{t}}=\mu_{\mathrm{t}}+\beta_{0} \mu_{\mathrm{t}}+\beta_{1} \mu_{\mathrm{t}-1}+\beta_{2} \mu_{\mathrm{t}-2}
$$

then it is an $\mathrm{MA}(2)$ process. When (5) and (6) are combined, we can have

$$
\begin{gathered}
\mathrm{Y}_{\mathrm{t}}=\mu_{\mathrm{t}}+\beta_{0} \mu_{\mathrm{t}}+\beta_{1} \mu_{\mathrm{t}-1}+\beta_{2} \mu_{\mathrm{t}-2}+\ldots \ldots+\beta_{I} \mu_{\mathrm{t}-\mathrm{I}} \\
\mathrm{Y}_{\mathrm{t}}=\mu_{\mathrm{t}}+\beta_{0} \mu_{\mathrm{t}}+\sum_{i=1}^{q} \beta_{i} \mu_{t-i}
\end{gathered}
$$

is an $\mathrm{MA}(\mathrm{q})$ process. In short, a moving average process is simply a linear combination of white noise error terms.

It is quite likely that $\mathrm{Y}$ has characteristics of both AR and MA and is therefore ARMA. It can be written as

$$
\mathrm{Y}_{\mathrm{t}}=\sum_{i=1}^{p} \alpha_{i}\left(\mathrm{Y}_{\mathrm{t}-\mathrm{i}}\right)+\mu_{\mathrm{t}}+\mu_{\mathrm{t}}+\beta_{0} \mu_{\mathrm{t}}+\sum_{i=1}^{q} \beta_{i} \mu_{t-i}
$$

where $\mu_{\mathrm{t}}$ is expected as 0 .

$$
\mathrm{Y}_{\mathrm{t}}=\beta_{0} \mu_{\mathrm{t}}+\sum_{i=1}^{p} \alpha_{i}\left(\mathrm{Y}_{\mathrm{t}-\mathrm{i}}\right)+\sum_{i=1}^{q} \beta_{i} \mu_{t-i}
$$

or commonly written as

$$
\mathrm{Y}_{\mathrm{t}}=\theta+\alpha_{1} \mathrm{Y}_{\mathrm{t}-1}+\beta_{0} \mu_{\mathrm{t}}+\beta_{1} \mu_{\mathrm{t}-1}
$$

$\theta$ represent a constant term. In general, in an $\operatorname{ARMA}(\mathrm{p}, \mathrm{q})$ process, $\mathrm{p}$ was autoregressive and $\mathrm{q}$ was moving average terms.

Equation (10) can also be written

$$
\mathrm{Y}_{\mathrm{t}}-\sum_{i=1}^{p} \alpha_{i}\left(\mathrm{Y}_{\mathrm{t}-\mathrm{i}}\right)=\beta_{0} \mu_{\mathrm{t}}+\sum_{i=1}^{q} \beta_{i} \mu_{t-i}
$$

or equivalent by

$$
\left(1-\sum_{i=1}^{p} \alpha_{i} L^{i}\right) Y_{t}=\left(1+\sum_{i=1}^{q} \beta_{i} L^{i}\right) \beta_{0} \mu_{\mathrm{t}}
$$

Furthermore, there is another ARMA(p,q) development model called ARIMA(p,d,q), where $p$ is the order (number of time lags) of the autoregressive (AR) model, $d$ is the degree of difference needed to makes the data stationary, and $q$ is the order of the moving average (MA) model [29].This model is used to solve many economic time series problems that are nonstationary, that is, they are integrated. 
George Box and Gwilym Jenkins formulated the Box Jenkins methodology to develop the ARIMA model, which gives the best fit to underlie time-series observations and meets the principle of parsimony. The critical thing to remember is that to use the Box-Jenkins methodology, we must have either a stationary time series or a time series that is stationary after one or more differencing.

The steps for implementing ARIMA are creating stationarity of the model; identifying autocorrelation function $(\mathrm{ACF})$ and partial autocorrelation function (PACF) of the sample data to determine the order of the model (the residual lag value or $\mathrm{q}$ and the dependent lag value or p); selecting the best ARIMA model based on the smallest number of parameters; checking the feasibility of the model specifications; and forecasting [30].

For example, $(1-L)^{d}$ is a unit root of $\left(1-\sum_{i=1}^{p} \alpha_{i} L^{i}\right)$, so:

Then (13) can be rewritten as:

$$
\left(1-\sum_{i=1}^{p} \alpha_{i} L^{i}\right)=\left(1-\sum_{i=1}^{p} \varphi_{i} L^{i}\right)(1-L)^{d}
$$

$$
\begin{aligned}
& \left(1-\sum_{i=1}^{p} \varphi_{i} L^{i}\right)(1-\mathrm{L})^{\mathrm{d}} \mathrm{Y}_{\mathrm{t}}=\left(1+\sum_{i=1}^{q} \theta_{i} L^{i}\right) \varepsilon_{t} \\
& \left(1-\sum_{i=1}^{p} \varphi_{i} L^{i}\right)(1-\mathrm{L})^{\mathrm{d}} \mathrm{Y}_{\mathrm{t}}=\delta+\left(1+\sum_{i=1}^{q} \theta_{i} L^{i}\right) \varepsilon_{t}
\end{aligned}
$$

An ARIMA (p, d, q) process $=\frac{\delta}{1-\sum \varphi_{i}}$

\section{FINDINGS AND DISCUSSION}

Figure 1 shows total rubber exports from Southeast Asian countries to Central European countries: Bulgaria, Czech Republic, Hungary, Poland, Romania, and Slovenia. Indonesia began to export rubber to Central European countries in 1990, with the leading destination in Czech Republic, Hungary, Poland, and Romania. Furthermore, Indonesia began exporting rubber to Bulgaria and Slovenia in the mid-1990s. Indonesia has been the primary exporter to these countries until this day. Even the share of rubber exports to Bulgaria, Poland, Romania, and Slovenia continued to increase. In contrast, the share of exports to the Czech Republic began to decline due to being taken over by Vietnam.

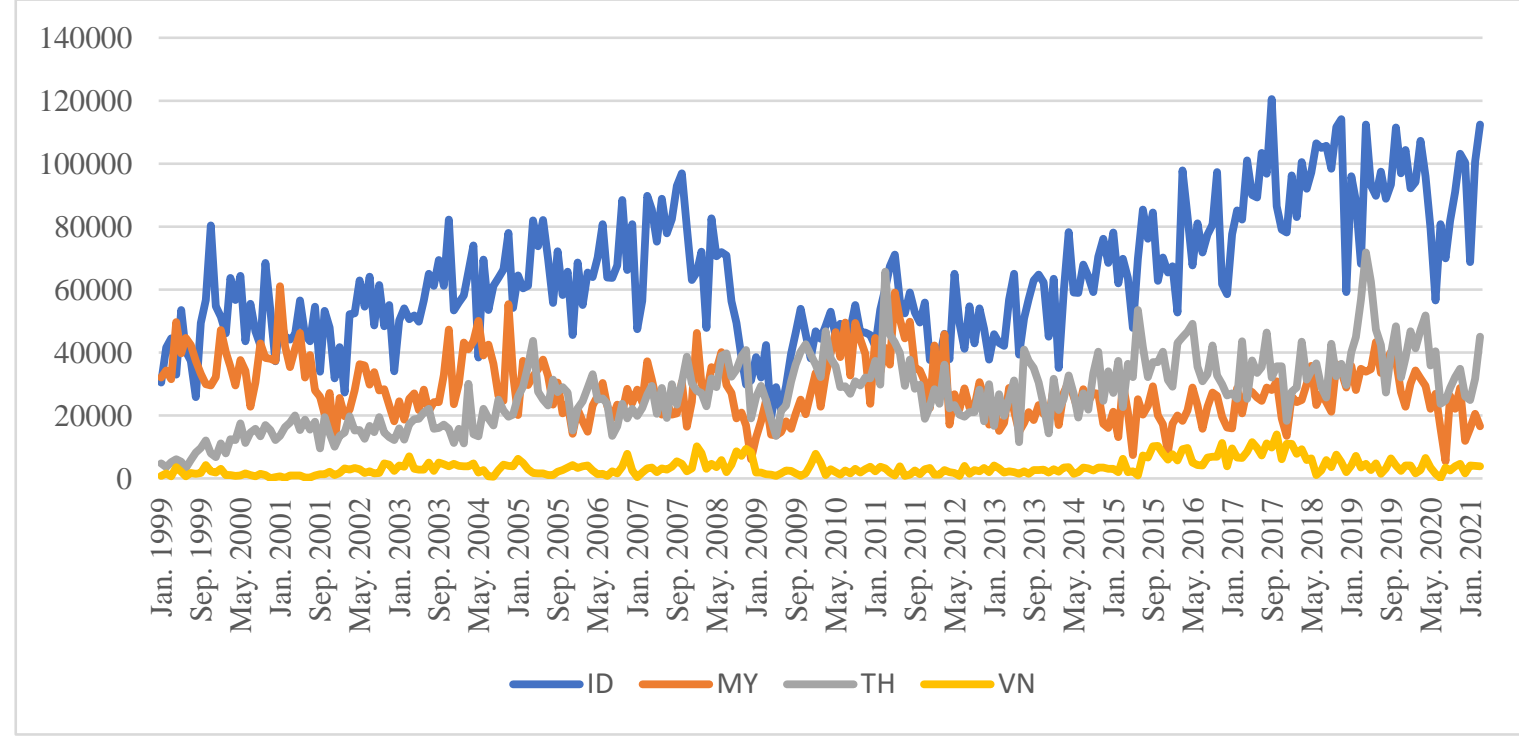

Figure 1. Southeast Asian rubber exports quantity to Central Europe during January 1999 - March 2021 (in quintals)

Source: Eurostat (2021) 
Rubber has been grown in Vietnam for over 120 years or since the French colonial era. Rubber remains pioneering in economic, political, cultural, and social development in Vietnam today [31]. But, not all rubber plantations in Vietnam have attained high levels of technical efficiency. Only $21 \%$ of Vietnam's state rubber farms achieve it [32].

Thailand, another rubber exporter, began exporting rubber to Central Europe in 2000. Thailand's share of rubber exports continued to grow rapidly, especially in Poland and Romania, indicating that the expansion was a huge success. Thailand has several rubber development policies, like conducting research on drought-resistant plant breeding, developing production technology, increasing the rubber and tire products industry's competitiveness, and integrating into downstream industries. As a result, Thai rubber production is favorable [33,34].

Malaysia was Indonesia's biggest rival in 1990, but its market share is declining due to being taken over by other countries. Malaysia faces several problems, including poor management, limited capital access, and slow farmer regeneration. The government began to reduce subsidies, resulting in decreased productivity. Meanwhile, Malaysia's overall consumption of natural and synthetic rubbers continues to increase. As a result, they have decreased natural rubber exports to another country while increasing imports from Thailand and Côte d'Ivoire [35].

One reason for the massive rubber exports from Southeast Asia to Central Europe is the free trade agreement. The European Union signed free trade agreements with Vietnam in 2012, Indonesia in 2016 and is now negotiating with Thailand and Malaysia. The focus of the trade liberalization agreement is to increase the intensity of trade relations by reducing tariff and nontariff barriers, increasing trade liberalization and investment in services and improving technological advances and skills in the goods, services and investment sectors. Now, the average of the EU's standard external tariff (CET) imposed on natural rubber imports into Central Europe is just $0-0.32 \%$ [36].

\section{Performance of Indonesian Rubber Exports}

From figure 1, it can also be seen that Indonesia dominates on rubber exports to Central Europe. The main destinations for Indonesian rubber exports were Poland, Romania, and Hungary (Table 1). The number of Indonesian rubber exports to Slovenia is also high, but this country is the only transit place for Indonesian rubber exports. This is because only Slovenia has ports in the Central European area, while other countries are isolated in the European continent. The decision to export through the Slovenian Koper port was taken to save costs and time compared to the ports of Hamburg and Rotterdam. After arriving at the Slovenian Koper port, rubber from Indonesia will be distributed to other countries in the Central European region.

Table 1. Descriptive statistics of Indonesian rubber exports to Central European countries during January 1999 -

\begin{tabular}{lcrrrr}
\multicolumn{1}{c}{ Variable } & Obs & \multicolumn{1}{c}{ Mearch 2021} & Std. Dev. & Min & Max \\
\hline DECLARANTP $\sim$ D & 0 & & & & \\
Bulgaria & 267 & 24.20 & 88.28 & 0 & 806 \\
Czechia & 267 & 10035.43 & 5391.81 & 0 & 24658 \\
Hungary & 267 & 10305.21 & 9709.92 & 0 & 45965 \\
Poland & 267 & 22041.40 & 9480.31 & 403 & 48662 \\
Romania & 267 & 14138.34 & 8887.61 & 788 & 38176 \\
Slovenia & 267 & 7529.36 & 3672.01 & 0 & 21462 \\
Total & 267 & 64073.94 & 20594.67 & 19260 & 120521 \\
\hline Source: Eurostat, processed (2021) & & & & &
\end{tabular}

Bulgaria and the Czech Republic are potential destinations for Indonesian rubber exports. As stated earlier, exports to Bulgaria only started in 2009 and are rapidly increasing. Bulgaria re-exports rubber to other European Union countries. Meanwhile, Vietnam has taken over the Czech Republic's rubber export market. This happened not because the Indonesian 
rubber price was higher than Vietnam, but because Vietnam had already signed a free-trade agreement with the European Union.

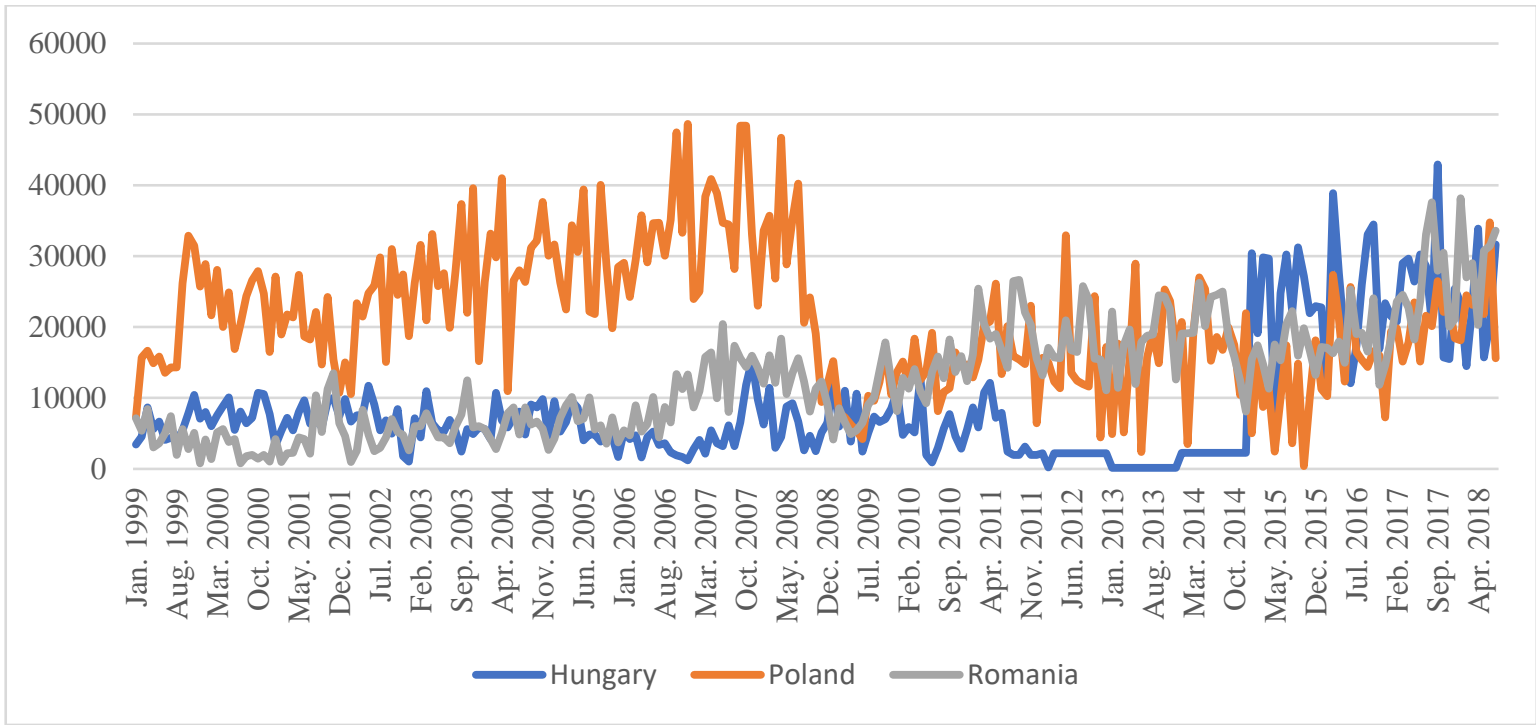

Figure 2. Indonesian rubber exports quantity to Central European countries during January 1999 - March 2021 (in quintals)

Source: Eurosatat (2021)

Poland is the leading importer of Indonesian rubber in Central Europe, followed by Romania and Hungary (Figure 2). According to Landesmann [37], the rubber industry is growing rapidly in the three countries. Since 1997, the profitability of the Polish rubber industry has risen by more than 5\%, with the highest investment growth reaching $49.9 \%$. In the same period, Hungary's rubber industry contributed $22.21 \%$ of the country's manufacturing gross outputs, worth 41,5 billion forints. A lot of foreign investment has also flowed into Romania to establish rubber processing companies, especially tire manufacturing.

Rubber in all three countries is the most widely used commodity in tire plants. Rubber tire plants have been established in Poland since 1939, but their operations began in 1950. The factory was modernized and developed over the next period, 1954-1960. Then the tire manufacturing technology in Poland developed, so increased the rubber demand [38]. Like Poland, Romania's most significant rubber users are the tire plants [39].

The tire industry in Central Europe has attracted foreign investment. Bridgestone (Japan), Goodyear Dunlop (USA), and Michelin are only a few tire plants in Poland. Continental (Germany), Michelin (France), and Pirelli (Italy) all have factories in Romania. Large companies such as Continental, Goodyear, Michelin, Hankook (South Korea), and Bridgestone have formed joint ventures, acquired existing companies or built new firms in Hungary. Rubber imports in all three countries increased due to this growth $[13,37,40]$.

Next, rubber is also used for public construction and private facilities in Poland, Romania, and Hungary. In the road-building process, rubber and oily sludge can be used as an asphalt binder mixture. Since this mixture can withstand low temperatures of $-28{ }^{\circ} \mathrm{C}$, so the asphalt surface layer does not crack [41]. Another advantage of this material is reducing energy consumption to obtain asphalt mix for road paving [42]. Meanwhile, rubber can be injected into the hollow concrete blocks. As a result, mechanical wave reduction in composites maintaining approximately the same compressive and bending strengths as solid concrete blocks. It also makes the production process more accessible and cheaper [43]. 
The footwear industry also makes extensive use of rubber. This industry can accommodate a massive number of workers and is still growing today [44]. Rubber is also found in the medical sector, such as the rubber dams used by dentists [45].

Meanwhile, innovations in the use of rubber continue to develop in these three countries. Finally, rubber waste can be used as heat and electricity sources. This waste is processed by an anaerobic thermal decomposition (thermolysis/pyrolysis) used on an industrial scale and consists of the degradation of polymer bonds into low molecular weight [46].

Although rubber imports to Poland, Romania, and Hungary continue to increase, Indonesia must remain alert because Romanian and Hungarian rubber imports from EU countries have increased. As a result, the value of rubber imports from non-EU countries, such as Indonesia, has decreased [27,47].

\section{Forecast of Indonesian Rubber Exports}

After knowing Indonesian rubber exports to Poland, Romania, and Hungary, a forecast is necessary to see the improvement of these exports in the future. Before performing the ARIMA analysis, we used the Dicky-Fuller test to determine whether the data stationary (Table 2).

Table 2. Dicky-Fuller test for Indonesian rubber exports to Poland, Romania, and Hungary

\begin{tabular}{c|c|c|c|c}
\hline & & \multicolumn{3}{|c}{ Interpolated Dicky-Fuller } \\
\hline & Test-statistic & $1 \%$ critical value & $5 \%$ critical value & $10 \%$ critical value \\
\hline Poland Z(t) & -8.973 & -3.459 & -2.879 & -2.570 \\
Romania Z(t) & -9.123 & -3.459 & -2.879 & -2.570 \\
Hungary Z(t) & -5.912 & -3.459 & -2.879 & -2.570 \\
\hline
\end{tabular}

MacKinnon approximate $\mathrm{p}$-value for $\mathrm{Z}(\mathrm{t})=0.0000$

The Dicky-Fuller test results in Table 2 show that all data in each country are stationary. This can be seen from $\mathrm{Z}_{\text {stat }}<\mathrm{Z}_{\text {calc, }}$ or it can be said that $\mathrm{H}_{0}$ is rejected. In this way, Indonesian rubber exports to Poland, Romania and Hungary can be analyzed using the ARIMA model. Then, we perform analysis to determine AR and MA model orders for each country, resulting in a different ARIMA model. The findings of this analysis will result in several alternative ARIMA models. In theory, to select the best model, we use the results of BIC (Bayessian Information Criterion), AIC (Akaike's Information Criterion), ACF (Autocorrelation Function) and PACF (Partial Autocorrelation Function).

Following a model comparison, the best ARIMA for each country is as follows: Poland with $\operatorname{ARIMA}(1,0,5)$, Romania with $\operatorname{ARIMA}(2,0,1)$, while Hungary with $\operatorname{ARIMA}(2,0,1)$. There are several alternative models other than the model mentioned before; for example, Poland has two alternative models, $\operatorname{ARIMA}(1,0,2)$ and $\operatorname{ARIMA}(1,0,3), \operatorname{ARIMA}(1,0,1)$ and $\operatorname{ARIMA}(1,0,3)$ are alternative models that exist in Hungary, whereas $\operatorname{ARIMA}(1,0,1)$ and $\operatorname{ARIMA}(1,0,3)$ are alternative models that exist in Romania $(1,0,2)$. To determine the best model with robust forecasting, we use the BIC and AIC values in Table 3. The ARIMA model was selected from each country to be the best model in this study because it has the lowest AIC and BIC values compared to other alternative models. Furthermore, the residual pattern of ACF and PACF in the selected model has a relatively stable pattern within the $5 \%$ confidence level range. This can help provide robust forecasts (Figure 3 and Figure 4).

Table 3. Results of AIC and BIC for Indonesian rubber exports to Poland, Romania, and Hungary

\begin{tabular}{l|c|c|c|c|r|r}
\hline \multicolumn{1}{c}{ Model } & $\mathrm{N}$ & ll(null) & ll(model) & Df & AIC & BIC \\
\hline Poland & 267 & & -2729.886 & 8 & 5475.772 & 5504.47 \\
Romania & 267 & & -2616.819 & 5 & 5243.637 & 5261.573 \\
Hungary & 267 & & -2679.379 & 6 & 5370.757 & 5329.281 \\
\hline
\end{tabular}

Source: secondary data analysis (2021) 


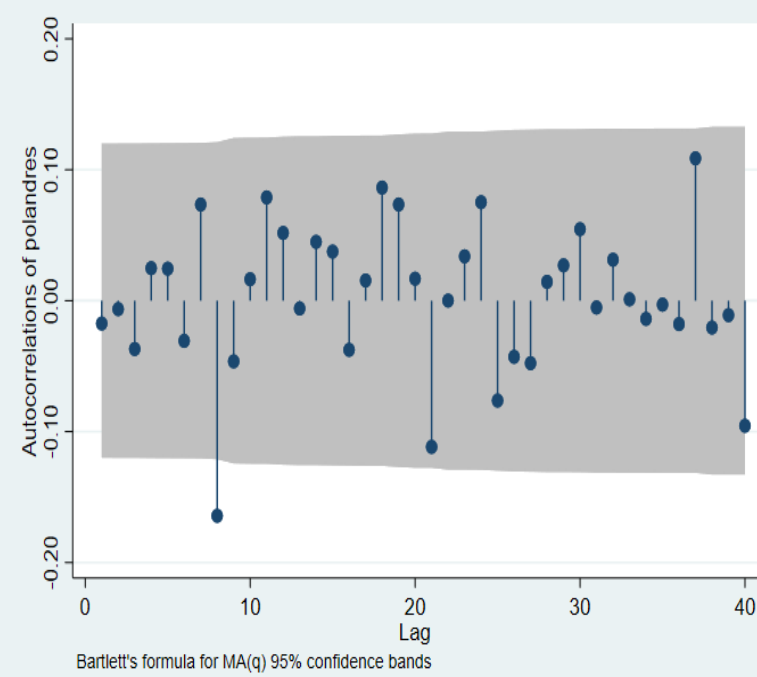

(a)

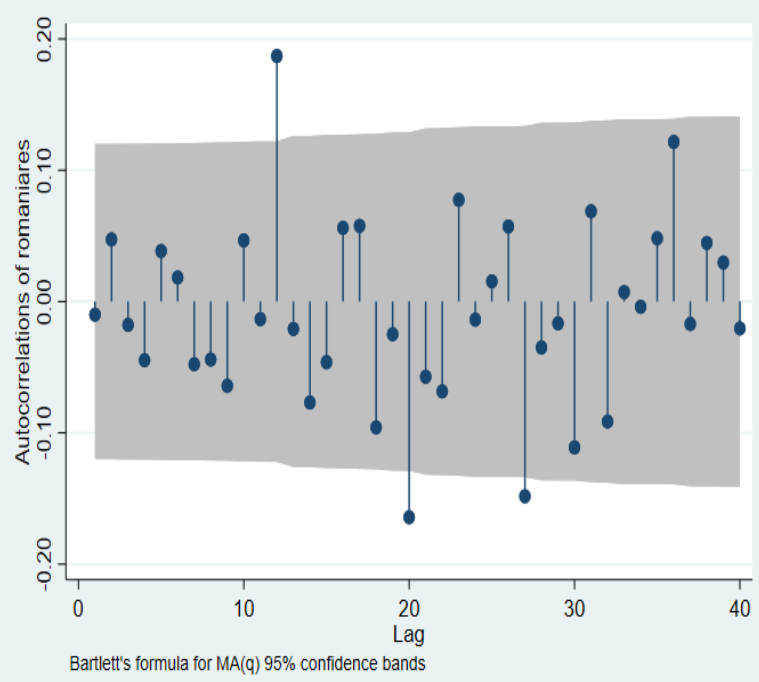

(b)

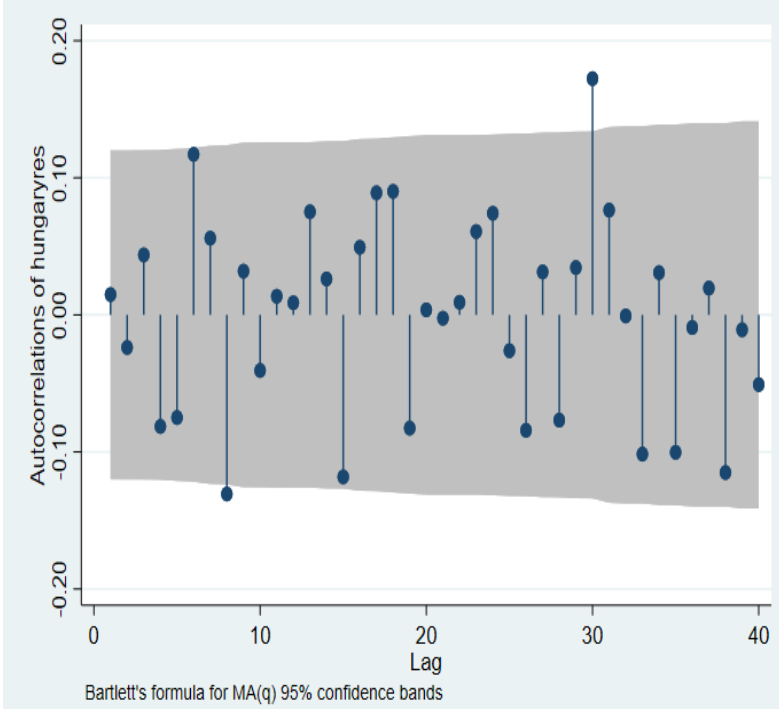

(c)

Figure 3. ACF residuals for Indonesian rubber exports to Poland (a), Romania (b), and Hungary (c) Source: secondary data analysis (2021)

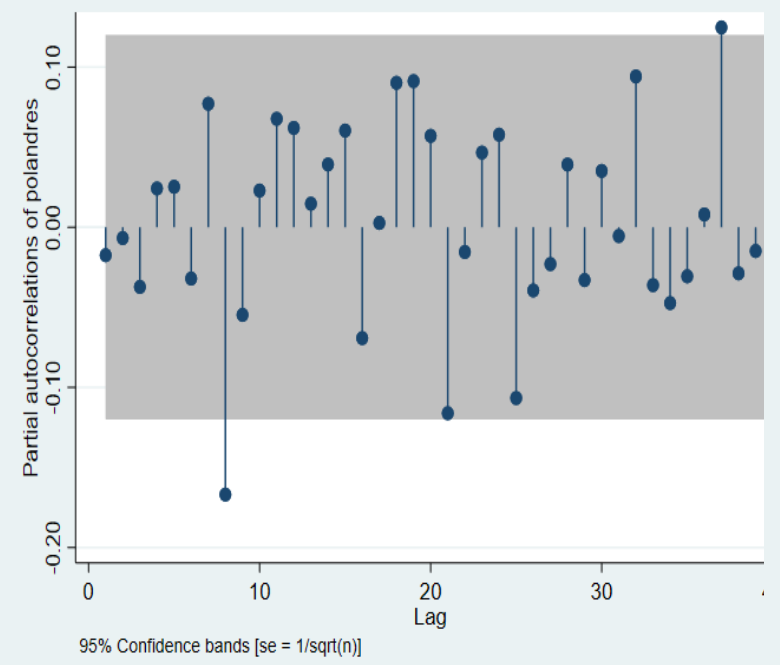

(a)

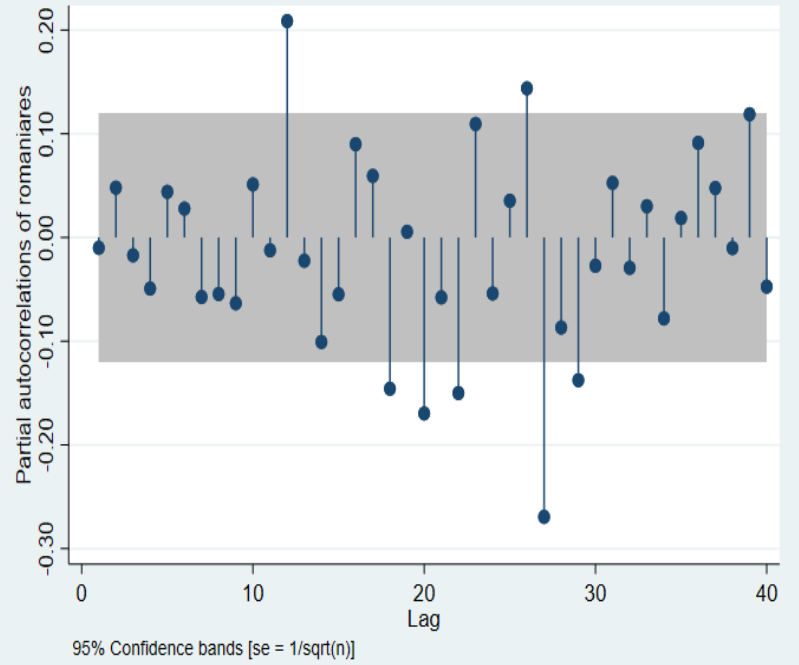

(b) 


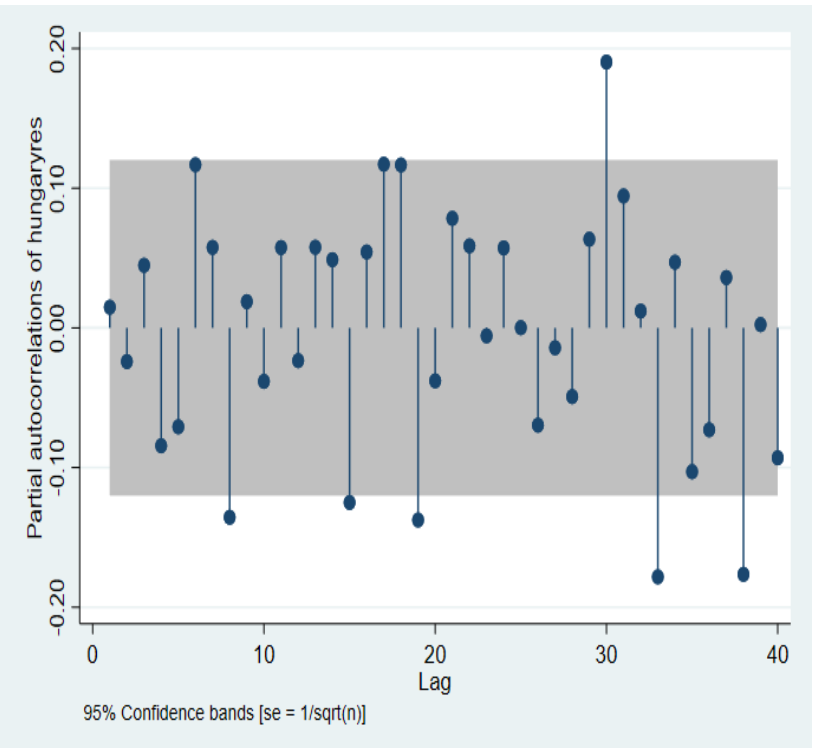

(c)

Figure 4. PACF residuals for Indonesian rubber exports to Poland (a), Romania (b), and Hungary (c) Source: secondary data analysis (2021)

After determining the best ARIMA model, the last stage of this study is forecasting Indonesian rubber exports to Poland, Romania, and Hungary. The results of the forecasting analysis are presented in Table 4.

Table 4. Forecast of Indonesian rubber exports to Poland, Romania, and Hungary from April 2021 - March 2022

\begin{tabular}{c|c|c|c}
\hline Time & Poland & Romania & Hungary \\
\hline $2021 \mathrm{~m} 4$ & $22,995.71$ & $31,356.36$ & $12,966.37$ \\
$2021 \mathrm{~m} 5$ & $28,042.55$ & $30,205.68$ & $13,692.37$ \\
$2021 \mathrm{~m} 6$ & $26,267.82$ & $29,885.60$ & $13,867.76$ \\
$2021 \mathrm{~m} 7$ & $25,162.64$ & $29,746.95$ & $13,573.72$ \\
$2021 \mathrm{~m} 8$ & $25,725.89$ & $29,648.28$ & $13,422.71$ \\
$2021 \mathrm{~m} 9$ & $25,375.70$ & $29,558.76$ & $13,372.73$ \\
$2021 \mathrm{~m} 10$ & $25,056.96$ & $29,471.67$ & $13,290.87$ \\
$2021 \mathrm{~m} 11$ & $24,766.83$ & $29,385.55$ & $13,191.45$ \\
$2021 \mathrm{~m} 12$ & $24,502.76$ & $29,300.08$ & $13,103.00$ \\
$2022 \mathrm{~m} 1$ & $24,262.39$ & $29,215.18$ & $13,021.16$ \\
$2022 \mathrm{~m} 2$ & $24,043.62$ & $29,130.83$ & $12,939.74$ \\
$2022 \mathrm{~m} 3$ & $23,844.48$ & $29,047.03$ & $12,859.87$ \\
\hline
\end{tabular}

Source: secondary data analysis (2021)

The results of forecasting analysis vary widely between countries. The most significant growth in Indonesian rubber exports was Poland, which initially increased to $21 \%$ but gradually declined. At the end of the forecasting period of this study, March 2022, Indonesian rubber exports to Poland were 3.6\% higher than in April 2021. The opposite condition occurred with Indonesian rubber exports to Romania which experienced a significant drop. Over the forecasted one-year period, Indonesian rubber exports fell by $7.36 \%$. Meanwhile, exports to Hungary grew by $6.95 \%$. This condition only lasted for a short period until it fell back to the beginning position. In other words, Indonesian rubber exports to Hungary are actually in a stagnant position.

Fluctuations in Indonesian rubber exports to the three countries arise due to several issues that must be resolved immediately. First, lousy quantity, quality, and post-harvest handling. Most of the rubber in Indonesia is old trees due to the limited number of natural rubber seedlings and farmers' reluctance to replace them with high-yielding clonal varieties. Its productivity continues to decline, and the product coagulates very quickly (decline in quality). 
Moreover, since the plantations are located far from the marketing place, the farmers decide to sell their products in the coagulated slabs. As a result, Indonesian rubber has lag productivity even though the country is still the largest producer globally $[7,48,49]$.

Second, capital constraints, which make it difficult for farmers to obtain bank loans. This is due to farmers' inability to repay loans or good administration. Finally, farmers have to borrow money from intermediaries and must sell their produce to these traders [49].

Third, the low rubber prices at the farmer level. This could be due to asymmetric marketing information. Farmers are not well informed about the marketing channels and the quality and price of rubber. They sell rubber based on previous experiences, habits in their environment, or debt deals that bind them to traders. Finally, traders always give prices arbitrarily, without distinguishing between good and poor-quality rubber. If the situation remains like this, it will encourage the conversion of rubber agroforestry areas into land for oil palm, food crops, and other crops [48,49].

Last, understanding the interests of Central European customers. Currently, Central European countries will follow EU sanitary \& phytosanitary regulations and environmental requirements. As a forest commodity, the rubber must meet the sanitation \& phytosanitary and chemical content standards, has a plant health certificate provided by the exporting country's appropriate competent authority, and get out from phytosanitary inspections at EU entry points [27].

EU consumers also expect products to have an Eco-Label because this means that the commodity has the least possible adverse environmental effects. The sustainability concept has not been completely implemented in Indonesia. Until now, the government tries to push natural rubber plantations to be more environmentally friendly [7]. According to some studies, the expansion of plantation areas in Indonesia, including rubber plantations, resulted in the conversion of around $28 \%$ of the total protected areas in peatlands [50,51].

\section{CONCLUSION}

Indonesia had to be creative in finding markets for its rubber exports due to competition with other countries, a trade war between the US and China, and the Covid-19 pandemic. One of the potential areas in Central Europe, which has many rubber processing industries. Over the last three decades, Indonesian rubber exports to Central Europe have increased, with Poland, Romania, and Hungary becoming the main destinations. Indonesian rubber exports to these countries are expected to increase. Over the last three decades, Indonesian rubber exports to Central Europe have increased, with Poland, Romania, and Hungary becoming significant destinations.

The short-term forecasting for Indonesian rubber exports to the three countries shows different results. Rubber exports to Poland will increase; on the other hand, exports to Romania will experience a decline. Meanwhile, exports to Hungary were relatively stable. This result was obtained using ARIMA estimation with different models for each country, respectively ARIMA $(1,0,5)$ in Poland, ARIMA $(2,0,1)$ in Romania, and ARIMA $(2,0,1)$ in Hungary.

We believe that Indonesia still has a comparative and competitive advantage for rubber exports to Central Europe. But, the Indonesian government requires several policies to realize the results of this study. First, improving cultivation. This is related to encourage the use of high-yield rubber varieties. Since this clone has been shown to increase the quantity and quality of products, it will provide many benefits for farmers and the government. This suggestion is also related to the monitoring program for implementing Good Agricultural Practices to meet consumer demand in Central Europe, especially sanitary and phytosanitary regulations, chemical content, and environmentally friendly products. In addition, farmers need easy access to capital. The government should encourage the allocation of the village funds (a grant from 
the central government to the village government that amounts to almost 5.5 million euros per village per year) to help farmers.

Second, improving the trading system to provide incentives for producers. So far, farmers sell rubber to intermediaries and get low prices. The government needs to build various marketing facilities, such as an auction market and set the selling price of rubber at the producer level. The government also needs to strengthen cooperation between industries and farmers in the smallholder nucleus plantation scheme. This scheme has proven to provide farmers with market and price certainty. Improvements in trading systems also need to be supported by complete transportation facilities to deliver rubber from farmers' production areas to the market. The construction of road and other transportation facilities needs to be continued, especially in rural areas

Third, Indonesian rubber must be actively promoted in Central European countries. This is to anticipate competition with other producer countries. Moreover, Indonesian rubber is cheaper than that of Thailand, Vietnam, and Malaysia. In addition, Indonesia has also taken advantage of free trade cooperation with the European Union because rubber exports are not subject to import tariffs. Indonesia must also strengthen cooperation with Slovenia, which has the only port in Central Europe. This is to facilitate rubber exports to Central Europe easier and save on transportation costs.

\section{REFERENCES}

[1] Hoang, V. V. Investigating the agricultural competitiveness of ASEAN countries. Journal of Economic Studies, 47(2), (2020) 307-332. https://doi.org/10.1108/JES-102018-0366

[2] International Rubber Study Group. World rubber industry outlook. International Rubber Study Group, Singapore.

[3] Malaysian Rubber Board. (2020). Natural rubber statistics 2019 Ministry of Plantation Industries and Commodities, Kuala Lumpur.

[4] Phuc, T. X., \& Nghi, T. H. (2014). Rubber expansion and forest protection in Vietnam. Tropenbos International Viet Nam, Hue City.

[5] International Rubber Consortium Limited. (2017). International tripartite rubber council International Rubber Consortium Limited, Bangkok.

[6] Kamaludin, R. Competitiveness and Exports Sustainability of the Indonesian Natural Rubber. Sriwijaya International Journal of Dynamic Economics and Business, 2(1), (2018) 85-98. https://doi.org/10.29259/sijdeb.v2i1.\%25p.

[7] Sitepu, M.H., \& McKay, A. Socio-technical Analysis of Natural Rubber Plantation in North Sumatera: Possibilities for sustaining supply. IOP Conference Series: Materials Science and Engineering, 801(1), 012114 (2020). https://doi.org/10.1088/1757$899 X / 801 / 1 / 012114$

[8] Oktora, S. I., \& Firdani, A. M. Natural Rubber Economics Between China and Southeast Asia: The Impact of China's Economic Slowdown. The Journal of Asian Finance, Economics and Business, 6(2), (2019) 55-62. https://doi.org/10.13106/JAFEB.2019.VOL6.NO2.55

[9] Antoni, M., \& Tokuda, H. A Determinant of Marketing System Choice by Rubber Smallholders in Indonesia. Bulgarian Journal of Agricultural Science, 25(4), (2019) 702-709.

[10] Ramli, N., Noor, A. H. S., Sarmidi, T., Said, F. F., \& Azam, A. H. M. Modelling the Volatility of Rubber Prices in ASEAN-3. International Journal of Business and Society, 20(1), (2019) 1-18. 
[11] English, V., \& Hoffmann, M. Business Intelligence as A Source of Competitive Advantage in SMEs: A Systematic Review. DBS Business Review, 2 (2018). https://doi.org/10.22375/dbr.v2i0.23

[12] Pfohl, H.-C., \& Large, R. Eastern-Western Supplier-Customer Relationships in Agricultural Machinery Industry: Results of An Empirical Investigation in The Czech Republic, Hungary, Romania, Ukraine, and Germany. European Journal of Purchasing \& Supply Management, 3(4), (1997) 177-187. https://doi.org/10.1016/S09697012(97)00012-9

[13] Poplawski, K. (2016). The role of Central Europe in the German economy. The political consequences. Centre of Eastern Studies (Osrodek Studiow Wschhodnich), Warsaw

[14] European Commision. (2017). Study on investment needs and obstacles along industrial value chains. European Commission, Brussels.

[15] Kocziszky, G., Benedek, J., \& Szendi, D. (2018). The impact of the 2008 financial crisis on household income and wealth in Visegrad countries. Regional Statistics, 8(1), 141167. https://doi.org/10.15196/RS080102

[16] William \& Marshall Strategy. (2021). Central Europe: Synthetic latex rubber market and the impact of Covid-19 in the medium-term. Williams \& Marshall Strategy, Sofia.

[17] Feenstra, R. C., \& Taylor, A. M. (2016). International trade. Macmillan Learning, New York.

[18] Salvatore, D. (2013). International economics (11th ed). John Wiley \& Sons, New Jersey.

[19] Krugman, P. R., \& Obstfeld, M. (2003). International economics: Theory and policy (6th ed). Pearson Education Inc, Boston.

[20] Gupta, S. (2014). Comparative Advantage and Competitive Advantage: An Economics Perspective and a Synthesis. Athens Journal of Business \& Economics, 1(1), 9-22. https://doi.org/10.30958/ajbe.1-1-1

[21] Cinquetti, C. A. (2018). Comparative advantages and demand in the new competitive Ricardian models. Foreign Trade Review, 53(1), 29-48. https://doi.org/10.1177/0015732516681884.

[22] Ansofino., \& Zusmella. (2017). Towards economic linkages and market integration in facing ASEAN economic community: Case study West Sumatra economy. International Journal of Economic Research, 14(15), 429-441.

[23] Ansofino., Zusmelia., Malinda, Y. \& Dahen, L. D. (2019). The spatial integration of crumb rubber markets within ASEAN countries. Academy of Strategic Management Journal, 18(4), 1-13.

[24] Sugiharti, L., Esquivias, M. A., \& Setyorani, B. (2020). The impact of exchange rate volatility on Indonesia's top exports to the five main export markets. Heliyon, 6(1), e03141. https://doi.org/10.1016/j.heliyon.2019.e03141.

[25] Khin, A. A., Bin, R. L. L., Kai, S. B., Teng, K. L. L., \& Chiun, F. Y. (2019). Challenges of the export for natural rubber latex in the ASEAN market. IOP Conference Series: Materials Science and Engineering, 548(1), 012024. https://doi.org/10.1088/1757899X/548/1/012024.

[26] Kaewsompong, N., Sriboonchitta, S., Maneejuk, P., \& Yamaka, W. (2016). Relationships among prices of rubber in ASEAN: Bayesian structural VAR model. Thai Journal of Mathematics, (2016), 101-116.

[27] Indonesian Trade Promotion Center Hungary. (2013). Market brief natural rubber products \& processing. Indonesian Trade Promotion Center Hungary, Budapest.

[28] Hyndman, R. J., \& Atahanasopoulos, G. (2018). Forecasting: Principles and practice OTexts, Melbourne, Australia. OTexts.com/fpp2. 
[29] Gujarati, D. N., Porter, D., \& Gunasekar, S. (2017). Basic econometrics $5^{\text {th }}$ edition McGrath Hill, New York.

[30] Fattah, J., Ezzine, L., Aman, Z., El Moussami, H., \& Lachhab, A. (2018). Forecasting of demand using ARIMA model. International Journal of Engineering Business Management, 10, 184797901880867. https://doi.org/10.1177/1847979018808673.

[31] Thi Nguyen, T. M. (2019). French colonialists' investment in and exploitation of natural rubber in Vietnam. Journal of Asian Development, 5(2), 101. https://doi.org/10.5296/jad.v5i2.14675.

[32] Son, T. V. H. (1993). Analysis of the technical efficiency of state rubber farms in Vietnam. Agricultural Economics, 9(3), 183-201. https://doi.org/10.1016/01695150(93)90047-G.

[33] Kaewboonma, N., Panawong, J., Pianhanuruk, E., \& Buranarach, M. (2017). Development of intelligent semantic search system for rubber research data in Thailand. AIP Conference Proceedings 1891, 020073. https://doi.org/10.1063/1.5005406.

[34] Tanielian, A. (2018). Sustainability and competitiveness in Thai rubber industries. The Copenhagen Journal of Asian Studies, 36(1), 50-78. https://doi.org/10.22439/cjas.v36i1.5512.

[35] Abdulla, I., \& Arshad, F. M. (2017). Exploring relationships between rubber productivity and R\&D in Malaysia. Outlook on Agriculture, 46(1), 28-35. https://doi.org/10.1177/0030727016689731.

[36] Manurung, H. (2018). Improving free trade agreement (FTA) between IndonesiaEuropean Union (EU) through comprehensive economic partnership (CEPA). Jurnal Asia Pacific Studies, 2(1), 23. https://doi.org/10.33541/japs.v2i1.667.

[37] Landesmann, M. (2000): Development and prospects of the rubber and plastic products sector in the Central and Eastern European countries. The Vienna Institute for International Economic Studies, Wien.

[38] Wilczyńska, U., Szadkowska-Stańczyk, I., Szeszenia-Dąbrowska, N., Sobala, W., \& Strzelecka, A. (2001). Cancer mortality in rubber tire workers in Poland. International Journal Occupational Medicine and Environmental Health, 14(2),115-125.

[39] Moebius, K. (1969). Rubber Industries in East European countries (Die kautschukindustrie in Den Ostblockstaaten). Gummi-Asbest-Kunststoffe, 22(10), 10211030.

[40] European Union. (2019). European Tire and Rubber Industry European Union, Brussels.

[41] Radziszewski, P., Sarnowski, M., Król, J., Pokorski, P., Jaskuła, P., Ryś, D., \& Pszczoła, M. (2019). Low-Temperature requirements for bitumen in Central East European road construction. The Baltic Journal of Road and Bridge Engineering, 14(2), 249-270. https://doi.org/10.7250/bjrbe.2019-14.442.

[42] da Graça, D. C. S., Cardoso, G., \& Mothé, C. G. (2019). Thermal behavior of asphalt binder with modifying agents from industrial residues. Journal of Thermal Analysis and Calorimetry, 138(5), 3619-3633. https://doi.org/10.1007/s10973-019-08371-w.

[43] Kulinski, K. (2019). On innovative concrete-rubber composite blocks reducing effects of dynamic mechanical impact: The review of structural solutions. IOP Conference Series: Materials Science and Engineering, 603(4), 042018. https://doi.org/10.1088/1757-899X/603/4/042018.

[44] Szeszenia-Dabrowska, N., Wilczynska, U., Kaczmarek, T., \& Szymczak, W. (1991). Cancer mortality among male workers in the Polish rubber industry. Polish Journal of Occupational Medicine and Environmental Health, 4(2), 149-157.

[45] Slowik, J., Jurczak, A., \& Zarow, M. (2011). The application of quality guidelines of the European society of edodontology in dental practice in Poland. Annales Academiae Medicae Stetinensis, 57(1),110-114. 
[46] Gołowicz, A., \& Wojciechowski, A. (2020). Fuels from waste for energy source diversification. Polityka Energetyczna - Energy Policy Journal, 23(2), 139-156. https://doi.org/10.33223/epj/124279.

[47] Iordan, M., \& Chilian, M. N. (2012). Romanian foreign trade with the European Uniondynamics and trends. Annals of the "Constantin Brâncuşi" University of Târgu Jiu, Economy Series, 4, 44-51.

[48] Gouyon, A. (2003). Eco-certification as an incentive to conserve biodiversity in rubber smallholder agroforestry systems: a preliminary study. World Agroforestry Centre, Nairobi.

[49] Arifin, B. (2005). Supply chain of natural rubber in Indonesia. Jurnal Manajemen Agribisnis, 2(1), 1-16. https://doi.org/10.17358/jma.2.1.1-16.

[50] Keenan, R. J., Reams, G. A., Achard, F., de Freitas, J. V., Grainger, A., \& Lindquist, E. (2015). Dynamics of global forest area: Results from the FAO Global Forest Resources Assessment 2015. Forest Ecology and Management, 352, 9-20. https://doi.org/10.1016/j.foreco.2015.06.014

[51] Uda, S. K., Hein, L., \& Sumarga, E. (2017). Towards sustainable management of Indonesian tropical peatlands. Wetlands Ecology and Management, 25(6), 683-701. https://doi.org/10.1007/s11273-017-9544-0. 